ПЕТРЕНКО О. М., к.т.н., доцент кафедри електричного транспорту (Харківський національний університет міського господарства імені О.М. Бекетова), ЛЮБАРСЬКИЙ Б.Г., д.т.н., професор кафедри електричного транспорту та тепловозобудування (Національний технічний університет «Харківський політехнічний інститут»)

\title{
Оптимізація керування мотор-вентилятором охолодження тягових двигунів вантажного локомотива 3 асинхронним тяговим приводом при русі на ділянці з заданим профілем та графіком руху
}

Робота присвячена розробиі методики оптимізації керування мотор-вентилятором тягових двигунів вантажного локомотива з асинхронним тяговим приводом при русі на ділянці з заданим профілем та графіком руху. Особливістю методики є таке: методика основана на розв'язанні задачі умовної мінімізачії за критерієм економічної ефективності системи вентиляиї та охолодження методом Вейля за узагальненим золотим перетином.

Ключові слова: мотор-вентилятор охолодження тягових двигунів, оптимізація режимів роботи, критерій оптимізації, параметри оптимізації, тяговий асинхронний двигун, вантажний електровоз, еквівалентна теплова схема заміщення, рух на ділянці колї, перегрівання над температурою охолоджувального середовища.

\begin{abstract}
Актуальність роботи
Для охолодження та вентиляції сучасних локомотивів використовуються мотор-вентилятори, що входять як складова частина до примусової системи вентиляції та охолодження тягових двигунів. Загальна потужність цих систем становить близько 1,75-3,5 \% від часової потужності локомотива. Режими роботи тягового привода локомотива залежать від комплексу таких факторів: ваги потяга; профілю колії, графіка руху, кліматичних явищ (швидкості вітру, опадів та ін.), режимів роботи системи керування тяговим приводом, системи електропостачання (для електрорухомого складу) та ін. Потужність тягових двигунів та втрати в елементах їх конструкції також відрізняються для кожного з випадків використання локомотива.

Теплові процеси у тягових двигунах характеризуються великими значеннями постійної часу, що може становити $10 . .30$ хв [1 - 6]. Нагрів двигуна до постійної температури може тривати $35 \ldots 100$ хв [1 - 6]. Однак електромеханічні процеси при русі електрорухомого складу більш динамічні. Режим роботи тягового привода може змінюватися кілька разів за одну хвилину. Тому для визначення теплового стану тягового двигуна необхідно врахування теплового навантаження за весь час роботи $[1,2]$. У зв'язку з тим, що при роботі тягового привода поширені режими вибігу та механічного (пневматичного) гальмування,
\end{abstract}

(C) О. М. Петренко, Б. Г. Любарський, 2017 при яких перетворення енергії у тяговому двигуні не відбувається і він перебуває в процесі охолодження, максимальна температура тягового двигуна може бути значно нижче за температуру, що встановилася, та вимагати значно менш потужної системи охолодження. В роботі розглядається розв'язання цієї задачі для найбільш поширених у цей час при виробництві асинхронних тягових двигунів (АТД) на прикладі їх застосування на вантажному локомотиві.

Таким чином, оптимізація керування моторвентилятором $€$ актуальним науково-технічним завданням для залізничного транспорту, яке можливо вирішити на основі сучасних інформаційних технологій 3 застосуванням методів оптимізації як режимів роботи тягового привода з АТД, так і руху потяга на ділянці колії за оптимальною траєкторією руху, а також 3 використанням системи вентиляції і охолодження АТД, що керується та працює в оптимальних режимах.

Для вирішення цього завдання можливі такі шляхи: зменшення втрат в елементах конструкції тягових двигунів та підвищення ефективності системи охолодження. Оптимізація процесів проектування тягових двигунів, що поширена на більшості підприємств провідних електротехнічних виробників, дозволяє створювати оптимальні за ККД тягові двигуни [1]. Однак режими їх роботи на електрорухомому складі, який рухається з різною швидкістю та при різних режимах навантаження, значно знижують загальний ККД електрорухомого складу [1,7-10]. Визначення оптимальних за енергоспоживанням режимів руху дозволяє підвищити ефективність системи охолодження 
тягових двигунів [1, 7 - 10]. Іншим шляхом підвищення системи охолодження $\epsilon$ створення оптимального керування мотор-вентилятором, що включає до себе температуру його ввімкнення та частоту його обертання.

Мета роботи: розробка методики оптимізації керування мотор-вентилятором охолодження тягових двигунів вантажного локомотива 3 асинхронним тяговим приводом при русі на ділянці з заданим профілем та графіком руху.

\section{Матеріал і результати досліджень \\ Для досягнення поставленої мети запропоновано застосування методів умовної оптимізації параметрів системи охолодження та вентиляції АТД локомотива. \\ Як критерій у дослідженні було обрано критерій економічної ефективності $k_{e, e}$ у зв'язку 3 тим, що основними витратами при роботі ЕРС є витрати на його експлуатацію, що пов'язано $з$ досить тривалим строком життєвого циклу транспортних засобів (від 10 до 50 років), який визначається за виразом $[11,12]$}

$k_{e, e}=Q_{\text {охол }} /\left(n_{m \partial} Q_{a}\right)$,

де $n_{m \partial}-$ кількість тягових двигунів, що охолоджуються, з одним мотор-вентилятором, $Q_{\text {охол }}$ витрати енергії на охолодження, $Q_{a}$ - втрати енергії в активних частинах АТД.

У більшості конструкцій сучасного рухомого складу для привода мотор-вентиляторів охолодження тягових двигунів використовуються асинхронні двигуни, що живляться від некерованих джерел напруги та не мають регулювання частоти обертання. Регулювання режимів роботи здійснюється завдяки дискретному ввімкненню мотор-вентилятора 3 урахуванням температури в елементах конструкції тягових двигунів. Потужність асинхронних двигунів привода мотор-вентилятора обумовлюється частотою обертання колеса вентилятора та конструкцією системи вентиляції. У зв’язку з тим, що остання залежить від конструктивних та компонованих рішень, при створенні усього локомотива параметрами для розв'язання задачі оптимізації режимів роботи систем охолодження АТД обрані такі величини:

- найбільше перегрівання над температурою охолоджувального середовища в елементах конструкції, при якій умикаються мотор-вентилятори охолодження тягових двигунів $\left(t_{\text {отк }}\right)$;

- число пар полюсів асинхронного двигуна привода мотор-вентилятора $(p)$, що $є$ безрозмірною величиною та обумовлює частоту обертання колеса моторвентилятора.

Обмеження, що накладаються при розв'язанні задачі оптимізації параметрів системи охолодження та вентиляції, можна поділити на такі групи:

- обмеження у вигляді нерівностей, що накладаються на параметри оптимізації

$0<\mathrm{t}_{\text {отк }}<t_{\text {dop }}$

$1<p<14$

де $t_{d o p}-$ максимально допустиме перегрівання над температурою охолоджувального середовища для елементів конструкції тягового двигуна, що обумовлено вимогами до класу ізоляції та максимальними температурами до них;

- обмеження на число пар полюсів щодо приналежності до простору цілих чисел;

- обмеження, що накладаються на максимальний перегрів над температурою охолоджувального середовища елементів конструкції тягових двигунів, що виникає при русі локомотива 3 составом на ділянці колії з заданим профілем та графіком руху

$u_{\max }<u_{d o p}$

де $u_{\max }, u_{d o p}-$ вектори-стовпці перегрівань елементів АТД та допустимих значень цих перегрівань.

Розв'язання задачі оптимізації проводиться на прикладі перспективного вантажного електровоза, розробленого на базі вантажного тепловоза 2ТЕ25А, параметри тягового привода якого наведені в таблиці при русі з составами з 60 чотиривісними вагонами загальною масою 3600 тонн в режимі підтримання середньої швидкості в 20 км/год. Основні технічні характеристики тягових приводів подано в таблиці.

Таблиця

Основні технічні характеристики тягових приводів

\begin{tabular}{|c|c|}
\hline Параметр & Значення \\
\hline Назва базового рухомого складу & 2TE25A \\
\hline $\begin{array}{l}\text { Потужність тягового двигуна у } \\
\text { тривалому режимі }\end{array}$ & 470 \\
\hline $\begin{array}{l}\text { Номінальна } \\
\text { частота обертання, об/хв }\end{array}$ & 990 \\
\hline $\begin{array}{l}\text { ККД двигуна в номінальному } \\
\text { режимі, \% }\end{array}$ & 0,96 \\
\hline Коефіцієнт потужності, д.о. & 0,88 \\
\hline $\begin{array}{l}\text { Кількість тягових двигунів, } \\
\text { приєднаних до одного } \\
\text { перетворювача }\end{array}$ & 3 \\
\hline Тип тягового двигуна & АД917 \\
\hline Тип напівпровідникового ключа & $\begin{array}{l}\text { Infineon } \\
\text { FZ1500R33HE3 }\end{array}$ \\
\hline
\end{tabular}


Для розв’язання задачі аналізу оптимізації керування мотор-вентилятором запропоновано заздалегідь провести розв'язання тягової задачі при русі на ділянці колії з заданим профілем та графіком руху за оптимальною траєкторією, результати якої наведені на рис. 1. Далі визначити втрати в елементах АТД локомотива на підставі методики, що наведена у роботах $[8-10,13]$, результати яких наведено на рис. 2.

У зв'язку 3 відносно малою відстанню між станціями рух потяга зазначеною ділянкою здійснюється впродовж п'ятьох циклів, які відрізняються один від одного лише температурою елементів АТД.

За результатами цих залежностей визначаємо витрати енергії в активних частинах АТД, їх можна визначити за виразом

$Q_{a}=\sum_{n=1}^{5} \int_{T} P_{5}$, де $P_{1}-$ втрати у сталі статора; $P_{2}$ - втрати у роторі, $P_{3}-$ у пазовій частині обмотки статора, $P_{4}-$ у лобовій частині обмотки статора, $P_{5}-$ механічні втрати.

Ці результати є вхідними даними для розв'язання задачі аналізу, яка базується на методиці моделювання теплових режимів, що наведена в роботах [8-10]. Відповідно до цієї методики пропонується застосування універсальної еквівалентної теплової схеми, що дозволяє виконувати теплові розрахунки нестаціонарних режимів роботи АТД за різних систем охолодження. В роботах $[8-10,13]$ розглянуто використання універсальної теплової схеми для теплових розрахунків асинхронних двигунів регульованих електроприводів для двигунів зі ступенем захисту IP22, IP23, до яких належить АД 917. Його еквівалентна теплова схема зображена на рис. 3. Для розрахунку еквівалентної теплової схеми пропонується використати метод вузлових потенціалів для електричних кіл.

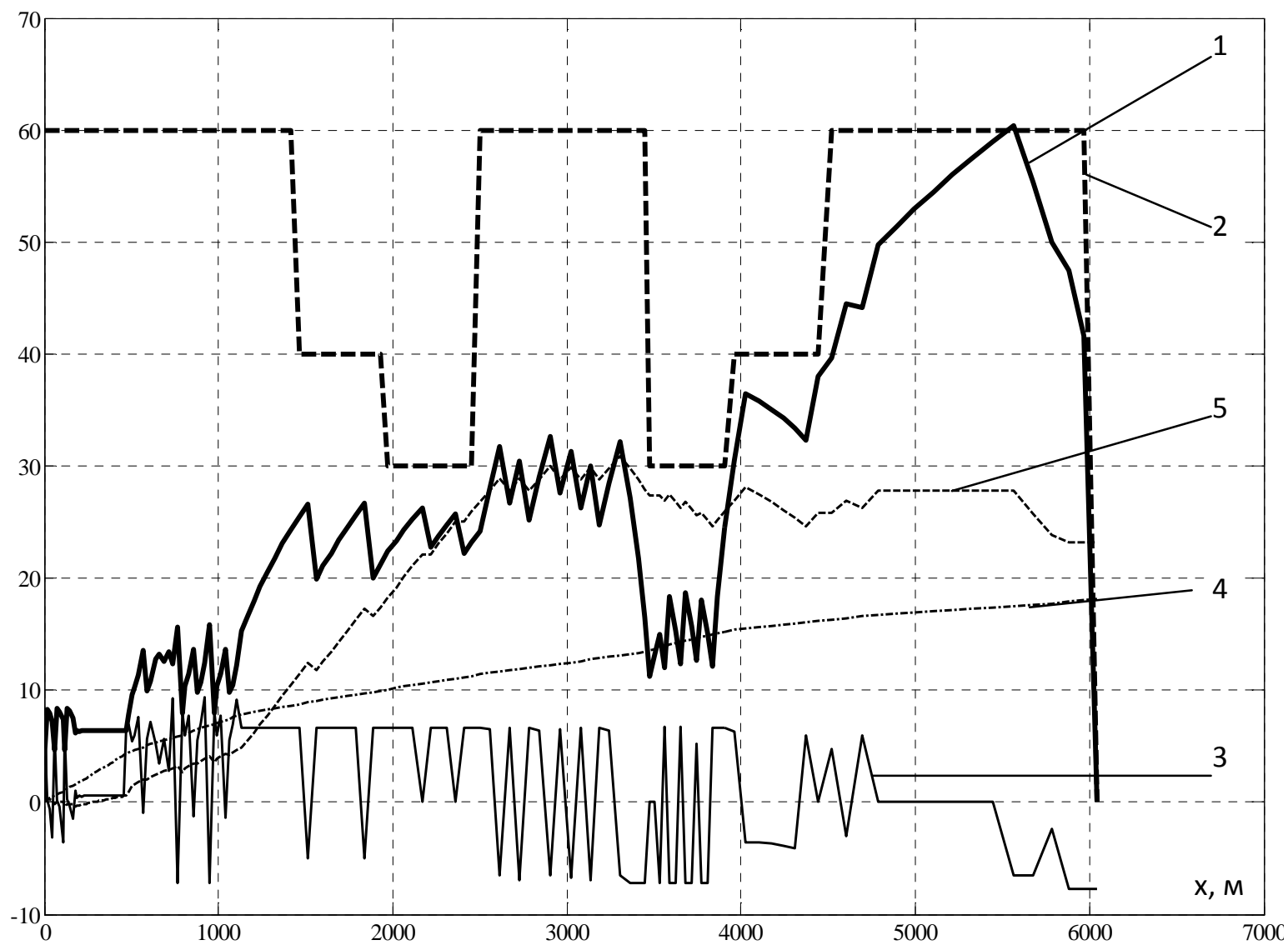

Рис. 1. Результати розв’ язання тягової задачі при русі вантажного потяга:

1 - швидкість руху $(v)$, км/год; 2 - обмеження швидкості , км/год; 3 - сила тяги/100, $\left(F_{r r} / 100\right)$ кН; 4 - час руху (t), хв, 5 - витрати енергії/10 (E/10), кВт·год 

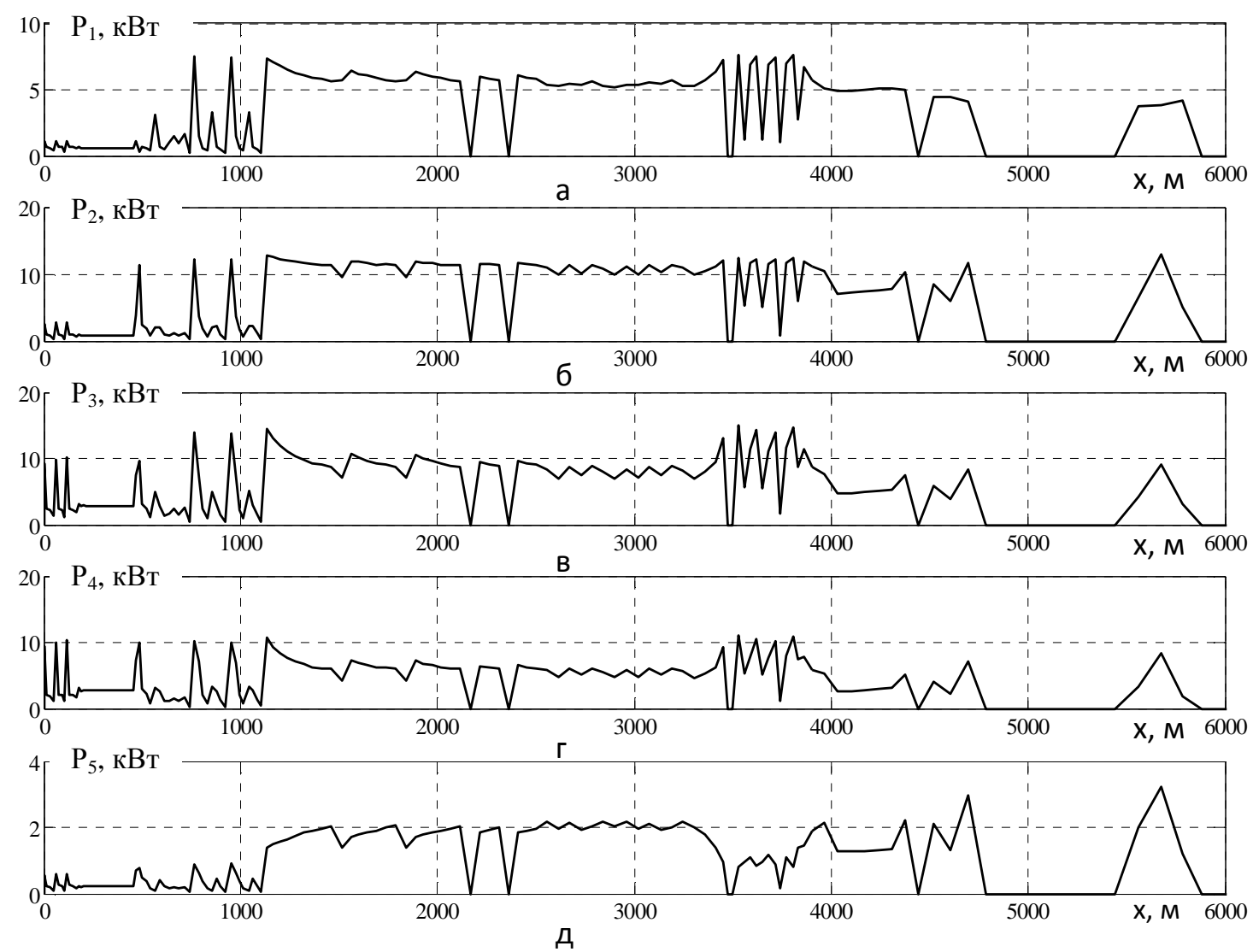

Рис. 2. Втрати тяговим двигуном:

a - втрати у сталі статора; б - втрати у роторі, в пазовій частині обмотки статора, г - у лобовій частині обмотки статора, д - механічні втрати

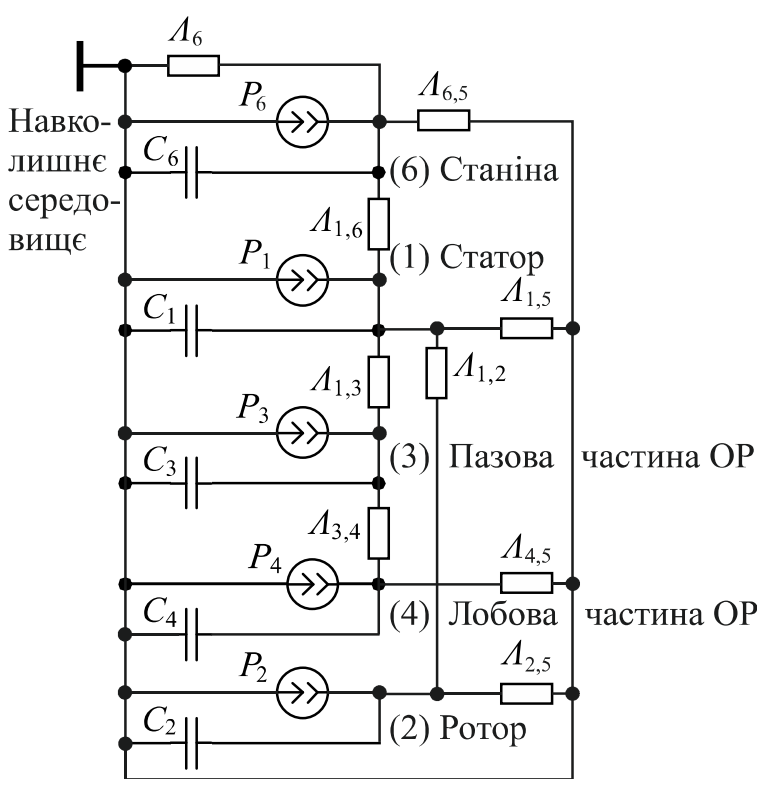

Рис. 3. Еквівалентна теплова схема для АТД з ступенем захисту IP22, IP23
На його підставі для запропонованої універсальної еквівалентної теплової схеми може бути складена система диференціальних рівнянь теплового балансу. У матричному вигляді система подана системою рівнянь

$$
\frac{d}{d t} u=[C]^{-1} \cdot[Д P+Л \times u]
$$

де $u$ - матриці-стовпці середніх перегрівань над температурою охолоджувального середовища у відповідних конструктивних елементах електричної машини, $C$ - матриця теплоємкостей відповідних конструктивних елементів, на які умовно розбивається АТД, ДР - матриця-стовпець потужностей тепловиділення у відповідних конструктивних елементах АТД, Л - матриця теплових провідностей.

Величини потужностей тепловиділення розраховуються при аналізі режимів роботи, що встановилися, або нестаціонарних, за даними втрат в елементах АТД. Параметри цих матриць створюються на підставі значень еквівалентних джерел струмів (втрат в елементах), які змінюються за часом в залежності від 
режиму роботи тягового привода, що наведені на рис. 2. Також змінюються і провідності схеми заміщення в залежності від потоку повітря, що створює моторвентилятор, та залежать від параметрів, які прийняті для розв'язання задачі аналізу.

Для визначення обмеження (4) проводиться аналіз змін перегрівань елементів АТД за весь час моделювання теплових режимів за виразом

$u_{\max }=\operatorname{MAX}(u)$.

Потужність двигуна, що потрібна для роботи моторвентилятора, визначається за виразом $[14,15]$

$P_{\text {вен }}=\frac{\Delta p Q_{v}}{\eta_{v}}$,

де $\Delta p$ - тиск повітря у вентиляторі; $Q_{v}$ - потік повітря у вентиляторі; $\eta_{v}-$ ККД вентилятора, який визначається за результатами вентиляційного розрахунку за методикою, наведеною в $[14,15]$, та залежить від частоти обертання мотор-вентилятора та числа пар полюсів його двигуна.
Втрати потужності на охолодження знаходяться за виразом

$Q_{\text {вен }}=\int_{T} P_{\text {вен }}$,

де $T$ - інтервал часу, в який працює мотор-вентилятор.

Результатом розв'язання задачі аналізу $\epsilon$ знаходження критерію оптимізації за виразом (1).

Метод розв'язання задачі. За результатами розв'язання тестових задач аналізу найкращий результат показав метод Вейля за узагальненим золотим перетином. Отримані такі оптимальні значення: $\mathrm{t}_{\text {отк }}=64,1{ }^{\circ} \mathrm{C}, \quad$ а кількість пар полюсів -5 . Розрахункова частота обертання мотор-вентилятора становить 570 об/хв. Потрібна потужність моторвентилятора складає 370 Вт, що значно менше за потужність базового мотор-вентилятора, що складає 22 кВт та має частоту обертання 2950 об/хв. Критерій оптимальності у розглянутій задачі становив значення 0,03 .

Результати моделювання теплових режимів АТД при оптимальному керуванні системи вентиляції подано на рис. 4.

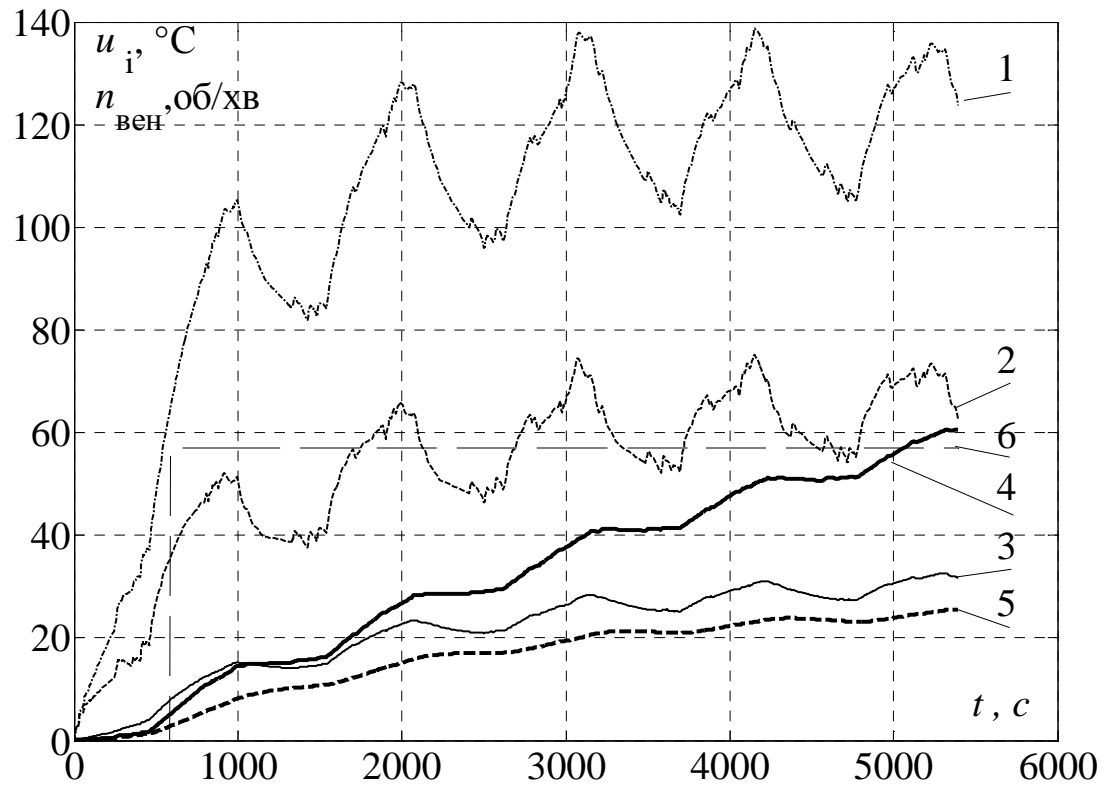

Рис. 4. Результати моделювання теплового стану тягового двигуна АД917 вантажного електровоза на ділянках колії. Залежності перегрівань над температурою охолоджувального середовища від часу:

1 - лобової частини обмотки статора, 2 - пазової частини обмотки статора; 3 - осердя статора, 4 - ротора; 5 - станини; 6 - частота обертання мотор-вентилятора

Як видно з графіків, найбільше перегрівання має лобова частина обмотки статора АТД, що складає $137,7^{\circ} \mathrm{C}$ на 4155 с 3 початку руху i не перевищує допустиме значення у $140^{\circ} \mathrm{C}$. Увімкнення мотор- вентилятора відбувається на 584 с з початку руху. Далі мотор-вентилятор працює зі штатною частотою обертання 570 об/хв. 


\section{Висновки}

Розроблено методику оптимізації керування моторвентилятором вентиляції та охолодження тягових двигунів вантажного локомотива 3 асинхронним тяговим приводом при русі на ділянці з заданим профілем та графіком руху, особливістю якої є таке:

- методика основана на розв'язанні задачі умовної мінімізації за критерієм економічної ефективності системи вентиляції та охолодження методом Вейля за узагальненим золотим перетином;

- в ролі параметрів оптимізації обрані такі величини: температура увімкнення мотор-вентилятора та кількість пар полюсів двигуна мотор-вентилятора, також встановлені обмеження у вигляді нерівностей;

- задача аналізу системи вентиляції та охолодження тягових двигунів основана на моделюванні теплових режимів АТД за узагальненою еквівалентною тепловою схемою.

Для тестової задачі оптимізації керування системи вентиляції та охолодження на прикладі перспективного вантажного електровоза, розробленого на базі вантажного тепловоза 2ТЕ25А, при русі з составом 360 чотиривісними вагонами загальною масою 3600 тонн в режимі підтримання середньої швидкості в 20 км/год отримані такі оптимальні значення: $64,1^{\circ} \mathrm{C}$;

- температура ввімкнення мотор-вентилятора -

- кількість пар полюсів двигуна мотор-вентилятора $-5$

- розрахункова частота обертання моторвентилятора становить 570 об/хв;

- потрібна потужність мотор-вентилятора складає 370 Вт, що значно менше за потужність базового моторвентилятора, що складає 22 кВт та має частоту обертання 2950 об/хв;

- критерій оптимальності у розглянутій задачі становив значення 0,03 .

Встановлено, що найбільше перегрівання має лобова частина обмотки статора АТД, що складає 137,7 ${ }^{\circ} \mathrm{C}$ на 4155 с $з$ початку руху і не перевищує допустиме значення у $140{ }^{\circ} \mathrm{C}$. Увімкнення мотор-вентилятора відбувається на 584 с 3 початку руху. Далі моторвентилятор працює зі штатною частотою обертання 570 об/хв.

\section{Література}

1. Любарський, Б. Г. Теоретичні основи для вибору та оцінки перспективних систем електромеханічного перетворення енергії електрорухомого складу [Текст]: дис... д-ра техн. $\begin{array}{llll}\text { наук } & \text { за } & \text { спеціальністю } & 05.22 .09\end{array}$ «Електротранспорт». - Харків: Національний технічнй університет «Харківський політехнічний інститут», 2014. - 368 с.

2. Гетьман, Г.К. Научные основы определения рационального мощностного ряда тяговых средств железнодорожного транспорта [Текст]: монография / Г.К. Гетьман. - Днепропетровск: Днепр. нац. ун-т ж/д трансп. им. акад. В. Лазаряна, 2008. - 444 c.

3. Мокін, О.Б. Моделювання та оптимізація руху багатомасових електричних транспортних засобів поверхнями зі складним рельєфом [Текст]: монографія / О. Б. Мокін, Б. І. Мокін. - Вінниця : ВНТУ, 2013. - 192 с.

4. Дмитриенко, В. Д. Моделирование и оптимизация процессов управления движением дизель-поездов [Текст] / В.Д. Дмитриенко, А.Ю. Заковоротный. Харьков: Изд. центр "НТМТ", 2013. - 248 с.

5. Петренко, О.М. Визначення ефективності електрорухомого складу. Основні положення та підходи [Текст] / О.М. Петренко, Б.Г. Любарський // Інформаційно-керуючі системи на залізничному транспорті. - 2015. - № 6. - С. 8-13

6. Todorov, Emanuel. "Optimal control theory." Bayesian brain: probabilistic approaches to neural coding (2006): 269-298.

7. Kappen, Hilbert J. "Optimal control theory and the linear bellman equation."Inference and Learning in Dynamic Models (2011): 363-387.

8. Петренко, О. М. Алгоритм синтезу експертної системи управління рухом електрорухомого складу на основі рішення рівняння ГамільтонаЯкобі-Беллмана [Текст] / О. М. Петренко, Б. Г. Любарський, М. Л. Глєбова // Вісник Нац. техн. ун-ту "ХПІ": зб. наук. пр. Темат. вип.: Математичне моделювання в техніці та технологіях. - Харків: НТУ "ХПІ", 2016. - № 6 (1178). - C. 89-95.

9. Петренко, О. М. Методика оптимізації режимів роботи асинхронного тягового приводу рухомого складу [Текст] / О.М. Петренко, І.В. Доманський, Б.Г. Любарський // Механіка та машинобудування. - 2016. - №1 - - C.59-67

10. Петренко, О. М. Математична модель оптимального керування рухом електрорухомого складу на підставі вирішення рівнянь ГамільтонаЯкобі-Беллмана [Текст] / О.М. Петренко, Б.Г. Любарський // Інформаційно-керуючі системи на залізничному транспорті. - 2016. - № 2. C. 19-24.

11. Борисенко, А. И. Аэродинамика и теплопередача в электрических машинах [Текст] / А.И. Борисенко, В.Г. Данько, А.И. Яковлев. - М.: Энергия, 1974. $560 \mathrm{c.}$

12. Борисенко, А. И. Охлаждение промышленных электрических машин [Текст] / А. И. Борисенко, О. Н. Костиков, А. И. Яковлев. - М.: Энергоатомиздат, 1983. - 296 с.

$\begin{array}{lll}\text { 13. Петрушин, } & \text { В. С. Расчет температур }\end{array}$ конструктивных элементов асинхронных двигателей в динамических режимах [Текст] / 
В. С. Петрушин, С. В. Рябинин, А. М. Якимец // Вісник Національного університету «Львівська політехніка». - 2000. - № 403. - С. 145-149.

14. Филиппов, И.Ф. Теплообмен в электрических машинах [Текст] / И. Ф. Филиппов. - Л.: Энергоатомиздат. Ленингр. отд-ние, 1986. - 256 с.

15. Сипайлов, Г.А. Тепловые, гидравлические и аэродинамические расчеты в электрических машинах [Текст] / Г. А. Сипайлов, Д. И. Санников, В. А. Жадан. - М.: Высш. шк., 1989. - 239 с.

\begin{abstract}
А. Н. Петренко, Б. Г. Любарский. Оптимизация управления мотор-вентилятором охлаждения тяговых двигателей грузового локомотива с асинхронным тяговым приводом при движении на участке пути с заданным профилем и графиком движения. Работа посвящена разработке методики оптимизации управления мотор-вентилятора тяговых двигателей грузового локомотива с асинхронным тяговым приводом при движении на участке с заданным профилем и графиком движения. Особенностью методики является следующее: методика основана на решении задачи условной минимизации по критерию экономической эффективности системы вентиляции и охлаждения методом Вейля по обобщеному золотому сечению.
\end{abstract}

Ключевые слова: мотор-вентилятор охлаждения тяговых двигателей, оптимизация режимов работы, критерий оптимизации, параметры оптимизации, тяговый асинхронный двигатель, грузовой электровоз, эквивалентная тепловая схема замещения, движение на участке пути, перегрев над температурой охлаждающей среды.

O.M. Petrenko, B.G. Lyubarskiy. Control optimization motor-fan cooling of traction engines of a freight locomotive with an asynchronous traction drive when driving on a section of the road with a specified profile and traffic schedule. The work is devoted to the development of methods for control optimization of the motor-fan of traction engines of a freight locomotive with an asynchronous traction drive when moving to sections with a specified profile and traffic schedule. The peculiarities of the methodology are the following: the method is based on the solution of the problem of conditional minimization by the criterion of the economic efficiency of the ventilation and cooling system by the Weyl method over the generalized golden section; as the optimization parameters, the following values are chosen: the temperature of the motor-fan on and the number of pole pairs of the motor-fan motor, and inequalities are also established; The task of analyzing the ventilation and cooling system of traction motors is based on modeling the thermal conditions of an asynchronous traction motor according to the generalized equivalent thermal scheme.

Keywords: Motor-fan cooling of traction motors, optimization of operating modes, optimization criterion, optimization parameters, traction induction motor, cargo electric locomotive, equivalent thermal substitution scheme, movement on the road section, overheating over the temperature of the cooling medium.

Надійшла 22.03.2017p.

О. М. Петренко, к.т.н., доцент кафедри електричного транспорту, ХНУМГ ім. О.М. Бекетова, Харків, Украӥна. E-mail: petersanya2007@mail.ru

Б. Г. Любарський, д.т.н., професор кафедри електричного транспорту та тепловозобудування, НТУ «ХПI», Харків, Україна. E-mail: lboris19111972@mail.ru

O.M. Petrenko, Ph.D., assistant professor of the Department «Electrical transport», O.M.Beketov National University of Urban Economic, Kharkiv, Ukraine. E-mail: petersanya2007@mail.ru

B.G. Lyubarskiy, Doctor of Engineering, Professor of the Department "Electrical transport and diesel locomotive", NTU "KhPI", Kharkiv, Ukraine. E-mail: lboris19111972@mail.ru. 